\title{
Ammonia volatilization with swine slurry injection and use of nitrification inhibitor
}

\author{
Luiz Paulo Rauber², Andréia Patrícia Andrade², Walter Santos Borges Júnior ${ }^{2}$, Álvaro Luiz Mafra², \\ Ariane Andreola ${ }^{2}$, Luciano Colpo Gatiboni ${ }^{2}$
}

10.1590/0034-737X201764030012

\begin{abstract}
The injection of nitrogen sources into the soil and use of nitrification inhibitor can improve the efficiency of applied nitrogen and minimize losses to the environment. The objective of this study was to evaluate the effect of swine slurry (SS) and urea in two modes of application in the soil (injected and surface), and the use of nitrification inhibitor on $\mathrm{NH}_{3}$ volatilization in a controlled environment, upon varying soil texture and soil $\mathrm{pH}$ conditions. The experiment was conducted under controlled conditions, or a Rhodic Kandiudox and Typic Hapludult soil in a completely randomized design in a 4 $\mathrm{x} 2 \times 2 \times 2$ factorial design with three replications. The study evaluated four fertilizers (urea, SS, SS +nitrification inhibitor (dicyandiamide-DCD) and control), two $\mathrm{pH}$ conditions (natural and limed) and two forms of fertilizer application (injected and surface), and two soils. The SS rate used was $21 \mathrm{~m}^{3} \mathrm{ha}^{-1}$, and the rate of the inhibitor was $10 \mathrm{~kg} \mathrm{ha}^{-1}$. The evaluations consisted in daily accumulated ammonia volatilization up to 14 days, and the percentage of soil nitrogen loss. The injection of fertilizers reduced emissions of ammonia in both soils and, limed soil had higher $\mathrm{N}$ losses by volatilization. The inhibitor did not increase the emission of ammonia in both soils.
\end{abstract}

Key words: manure; dicyandiamide; emission; nitrogen.

\section{RESUMO}

\section{Volatilização de amônia do solo com injeção de dejeto líquido suíno e inibidor de nitrificação}

A injeção de fontes de nitrogênio no solo e o uso de inibidor de nitrificação podem melhorar a eficiência do nitrogênio aplicado e minimizar perdas para o ambiente. O objetivo deste trabalho foi avaliar o efeito do DLS e da ureia em dois modos de aplicação no solo (injetado e superficial), e o uso de inibidor de nitrificação sobre a volatilização de $\mathrm{NH}_{3}$ em ambiente controlado, com condições variadas de textura e $\mathrm{pH}$ do solo. O experimento foi conduzido em condições controladas, em um Nitossolo e um Argissolo, com delineamento inteiramente casualizado, em esquema fatorial 4 x 2 x 2 × 2 com três repetições. Avaliou-se quatro fertilizantes (ureia, dejeto líquido suíno, dejeto líquido suíno+inibidor de nitrificação (dicianodiamida-DCD) e testemunha), duas condições de $\mathrm{pH}$ (natural e corrigido), duas formas de aplicação dos fertilizantes (injetado e superficial), e dois solos. A dose de dejeto suíno foi de $21 \mathrm{~m}^{3} \mathrm{ha}^{-1}$, e a do inibidor foi de $10 \mathrm{~kg} \mathrm{ha}^{-1}$. As avaliações consistiram em mensuração da volatilização de amônia diária e acumulada até o $14^{\circ}$ dia, e da porcentagem de $\mathrm{N}$ perdido em relação ao aplicado. A injeção reduziu as emissões de amônia em ambos os solos, e a correção do $\mathrm{pH}$ favoreceu as perdas de $\mathrm{N}$ por volatilização. O inibidor não aumentou a emissão acumulada de amônia em ambos os solos.

Palavras-chave: dicianodiamida; biofertilizante; emissão; nitrogênio.

\footnotetext{
Submitted on June $23^{\text {th }}, 2015$ and accepted on April 18 $8^{\text {th }}, 2017$.

${ }^{1}$ Part of doctorate's thesis of the first author.

${ }^{2}$ Universidade do Estado de Santa Catarina, Centro de Ciências Agroveterinárias, Lages, Santa Catarina, Brazil. sr_roiber@yahoo.com.br; andreiapatricia74@yahoo.com.br; waltersbjr@hotmail.com; alvaro.mafra@udesc.brariandreola@yahoo.com.br; lgatiboni@gmail.com

*Corresponding author: sr_roiber@yahoo.com.br
} 


\section{INTRODUCTION}

Many areas dedicated to swine farming in southern Brazil may be impacted by excessive and successive applications of swine slurry (SS), resulting in environmental constraints. The application of this organic material to the soil surface may promote ammonia $\left(\mathrm{NH}_{3}\right)$ volatilization and cause losses of up to $50 \%$ of the applied nitrogen $(\mathrm{N})$, reducing its fertilizing potential (Cameron $e t$ al., 2013).

Technologies used to mitigate the polluting effects and to enhance agronomic use of $\mathrm{N}$ present in animal wastes have been evaluated. The injection of SS is an recommended alternative and it is already adopted in countries of temperate climate, proving to be efficient in reducing volatilization of $\mathrm{NH}_{3}$ (Pote \& Meisinger, 2014). This reduction by soil injection is justified by the lower exposure to air and the increase in the adsorption of ammonium $\left(\mathrm{NH}_{4}^{+}\right)$in the soil, due to the greater contact with soil particles (Webb et al., 2014).

Another alternative is the use of nitrification inhibitors, which have been investigated in many countries in order to reduce nitrate $\left(\mathrm{NO}_{3}^{-}\right.$) leaching (Zaman \& Blennerhassett, 2010; Zhang et al., 2015; Gonzatto et al., 2016). Dicyandiamide (DCD) is one of the nitrification inhibitors used in other countries. This compound has bacteriostatic properties involved in the oxidation of $\mathrm{NH}_{4}^{+}$to nitrite $\left(\mathrm{NO}_{2}\right)$, reducing the action of bacteria Nitrosomonas (Singh \& Verma, 2008), by temporarily blocking the ammonium monooxygenase enzyme, which prolongs permanence of $\mathrm{NH}_{4}^{+}$in the soil. Thus, it is necessary to evaluate whether the application of this inhibitor interferes with the levels of $\mathrm{NH}_{4}^{+}$of the soil and affects the losses of $\mathrm{N}$ by volatilization (Vander Zaag et al. 2011).

These strategies used to reduce the environmental impact of SS, such as the injection and the use of the nitrification inhibitor, may present variable results on the volatilization of $\mathrm{NH}_{3}$ (Kim et al., 2012), depending on the soil conditions and the form in which the organic waste was applied.

Thus, the hypothesis of this work is that the combined use of the nitrification inhibitor and SS injection reduces $\mathrm{N}$ losses by $\mathrm{NH}_{3}$ volatilization, which would increase the efficiency of the use of this organic material as fertilizer.

The objective of this work was to evaluate the effect of SS and urea in two modes of application in the soil (injected and superface), and the use of nitrification inhibitor on $\mathrm{NH}_{3}$ volatilization in a controlled environment, upon varying conditions of texture and $\mathrm{pH}$ of the soil.

\section{MATERIALAND METHODS}

The experiment was carried out in a greenhouse under a completely randomized design, with three replications, in a $4 \times 2 \times 2 \times 2$ factorial scheme, which were, as follows: four fertilizers (urea, swine slurry (SS), SS+ nitrification inhibitor dicyandiamide-DCD) and control); two $\mathrm{pH}$ conditions (natural and corrected); two modes of fertilizer application (injected and surface); and two soils (clayey and sandy).

The experimental units consisted of polyethylene pots with a capacity of $700 \mathrm{~mL}$, whose dimensions were $7.5 \mathrm{~cm}$ in diameter, containing $250 \mathrm{~g}$ of dry soil, maintained with moisture of $70 \%$ of field capacity (FC) for Rhodic Kandiudox (clayey soil) and $60 \%$ of FC for the Typic Hapludult (sandy soil). Moisture was previously tested, allowing aerobic conditions for biological activity and good physical condition, not causing deformation of the soil aggregates during the handling and setting up of the experiment.

Swine slurry was collected from anaerobic manure storage tanks from a production system of swine finishing. SS was characterized according to a methodology described by Tedesco et al. (1995), with dry matter of 156 $\mathrm{g} \mathrm{kg}^{-1}$; total-N: $8.2 \mathrm{~kg} \mathrm{~m}^{-3}$; ammoniacal-N: $4.2 \mathrm{~kg} \mathrm{~m}^{-3}$; nitric$\mathrm{N}: 0.1 \mathrm{~kg} \mathrm{~m}^{-3} ; \mathrm{pH}$ : 6.6. The rate of SS applied was $21 \mathrm{~m}^{3} \mathrm{ha}^{-}$ ${ }^{1}$, based on the recommendation of $140 \mathrm{~kg} \mathrm{ha}^{-1}$ of $\mathrm{N}$ to reach an yield of $8 \mathrm{Mg} \mathrm{ha}^{-1}$ of mayze (CQFS-RS/SC, 2016). For the mineral fertilizer, the conventional urea $(45 \% \mathrm{~N})$ was applied at the same $\mathrm{N}$ rate of the SS.

The nitrification inhibitor used was dicyandiamide (DCD). This product is presented as a white, synthetic powder, consisting of $81 \%$ of DCD and $6.5 \%$ of N- (nbutyl) thiophosphoric triamide (NBPT) in its formulation. It is commercially used in the United States and tested under experimental conditions in Brazil. The inhibitor was mixed to SS at the time of soil application at the rate of 10 $\mathrm{kg} \mathrm{ha}^{-1}$ of active ingredient.

Fertilizer injection was performed on a tray by evenly mixing the sources of $\mathrm{N}$ (SS and urea (diluted in water)) with $250 \mathrm{~g}$ of soil. Moisture was standardized using water in the same volume of the SS, for the treatments with urea and in the control. For surface application, the sources of $\mathrm{N}$ were distributed with the aid of a pipette over soil surface in the pots.

The soils used in the study were a Rhodic Kandiudox, and a Typic Hapludult, collected in the 0.0$0.20 \mathrm{~cm}$ layer, air-dried and sieved in a $3-\mathrm{mm}$ mesh sieve. The chemical and physical properties determined by methodologies described by Tedesco et al. (1995) and according to the methodologies described by Embrapa (1997), respectively, observed in the Rhodic Kandiudox are, as follows: $\mathrm{pH}\left({ }_{\text {water }}\right): 4.8 ; \mathrm{P}: 2.9 \mathrm{mg} \mathrm{dm}^{-3} ; \mathrm{K}: 71 \mathrm{mg} \mathrm{dm}^{-3}$; organic matter: $36 \mathrm{~g} \mathrm{~kg}^{-1}$; sand $90 \mathrm{~g} \mathrm{~kg}^{-1}$; silt: $160 \mathrm{~g} \mathrm{~kg}^{-1}$; clay: $750 \mathrm{~g} \mathrm{~kg}^{-1}$. For the Typic Hapludult, the characteristics are the following: $\mathrm{pH}\left({ }_{\text {water }}\right): 4.2 ; \mathrm{P}: 3.1 \mathrm{mg} \mathrm{dm}^{-3} ; \mathrm{K}: 70 \mathrm{mg}$ $\mathrm{dm}^{-3}$; organic matter: $13 \mathrm{~g} \mathrm{~kg}^{-1}$; sand $690 \mathrm{~g} \mathrm{~kg}^{-1}$; silt: $70 \mathrm{~g}$ 
$\mathrm{kg}^{-1}$; clay: $240 \mathrm{~g} \mathrm{~kg}^{-1}$. A portion of each soil had its $\mathrm{pH}$ adjusted to $\mathrm{pH} 6.0$ by incubation for 30 days with dolomitic limestone (CaO: 29\%, $\mathrm{MgO}: 19 \%$ and PRNT: 100\%), as recommended by CQFS-RS/SC (2016).

The capture of soil volatilized $\mathrm{NH}_{3}$ was based on a work carried out by Tasca et al., (2011), performed in falcon tubes with a capacity of $15 \mathrm{~mL}$, containing $10 \mathrm{~mL}$ of $\mathrm{H}_{3} \mathrm{PO}_{4}$ $0.5 \mathrm{~N}$ with glycerin (1\%) and two tapes of filter paper ( $1 \mathrm{x}$ $8 \mathrm{~cm}$ ) soaked in this solution to increase $\mathrm{NH}_{3}$ contact surface with $\mathrm{H}_{3} \mathrm{PO}_{4}$. The falcon tubes were inserted by 2 $\mathrm{cm}$ into the soil, in the center of each experimental unit, where the pots were closed with a lid, which had six 2-mm holes to allow air circulation. Evaluations of $\mathrm{NH}_{3}$ were performed daily from the first to the eighth day and from the $11^{\text {th }}$ to the $14^{\text {th }}$ day after fertilizer application, with monitored temperatures in the greenhouse (Figure 1).

The amount of volatilized $\mathrm{NH}_{3}$ was determined daily by steam trapping in Kjeldahl semi-micro apparatus with distillation of a $10 \mathrm{~mL}$ aliquot, adding $10 \mathrm{~mL}$ of $\mathrm{NaOH} 10 \mathrm{M}$ in each sample (Tedesco et al., 1995).

By the end of the evaluations, the daily and accumulated ammonia emissions were calculated, by discounting the value of the control for each fertilizer. The total accumulated from the fertilizers was expressed as percentage of applied $\mathrm{N}$ (equivalent to $140 \mathrm{~kg} \mathrm{ha}^{-1}$ ). Emission of accumulated $\mathrm{NH}_{3}$ was adjusted by Mitscherlich equation, Eq.2 (Clay et al., 2012):

$\mathrm{Y}=\mathrm{A}\left(1-\mathrm{e}^{-\mathrm{bx}}\right)$

Where:

$\mathrm{A}$ and $\mathrm{b}$ - constants of the model, where $\mathrm{A}$ is the maximum theoretical value of accumulated ammonia and $b$ is the adjustment coefficient;

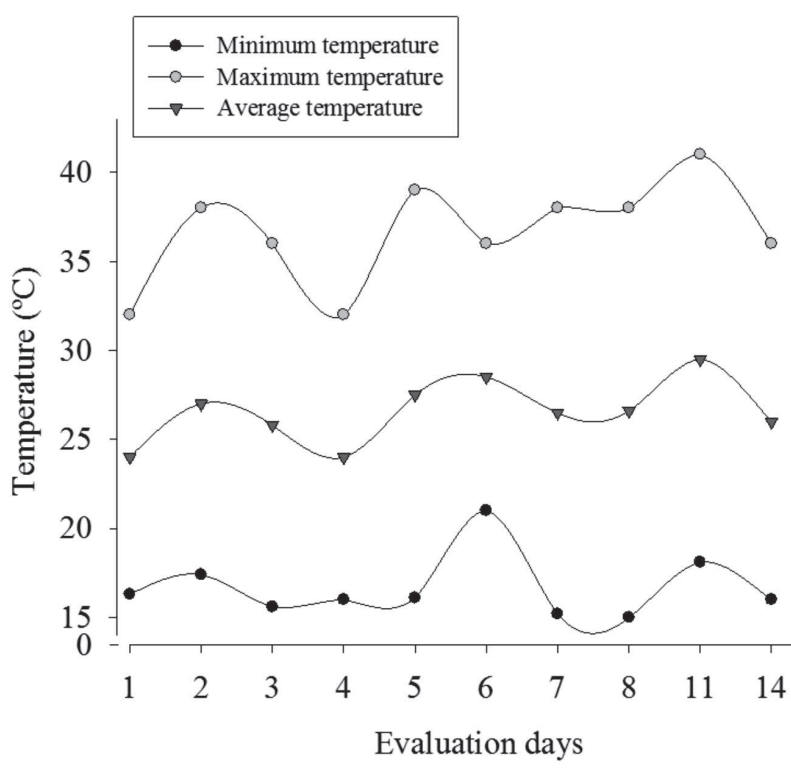

Figure 1: Minimum, maximum and average temperature during experiment period, under controlled conditions.
$\mathrm{Y}$ and $\mathrm{x}$ - dependent and independent variables, respectively.

Analysis of variance was performed by the $\mathrm{F}$ test and means of the experiments were compared by Tukey's test $(\mathrm{P}<0.05)$. For the emissions of accumulated ammonia and percentage of lost $\mathrm{N}$, the fertilizers and their modes of application were compared within the same $\mathrm{pH}$; and each fertilizer with the same mode of application at different $\mathrm{pH}$, both evaluating the soils separately. The statistical package used was SAS (2007).

\section{RESULTS AND DISCUSSION}

\section{Treatments main effect on daily volatization of ammonia}

The effects on the daily emissions of $\mathrm{NH}_{3}$ observed in clayey soil occurred for the type of fertilizer (Figure 2A) on the $3^{\text {rd }}, 6^{\text {th }}$ and $7^{\text {th }}$ day of evaluation. For the application mode and $\mathrm{pH}$, an effect was observed on the $3^{\text {rd }}$ and $6^{\text {th }}$ day after fertilizer application (Figure 2C; Figure 2E). In the sandy soil, daily emissions of $\mathrm{NH}_{3}$ displayed responses to fertilizers on the $1^{\text {st }}, 2^{\text {nd }}$ and $8^{\text {th }}$ day (Figure $2 \mathrm{~B}$ ), while for the application mode, an effect was found on the $1^{\text {st }}, 2^{\text {nd }}$, $5^{\text {th }}$ and $8^{\text {th }}$ day (Figure 2D). In the $\mathrm{pH}$ factor, the effects occurred on the $1^{\text {st }}, 3^{\text {rd }}, 4^{\text {th }}, 7^{\text {th }}, 11^{\text {th }}$ and $14^{\text {th }}$ (Figure 2 ) days.

The highest volatilizations were observed on the third day after fertilizer application (Figures 2A and Figure 2B), in both soils. At the peak of volatilization, the addition of SS differed from the other treatments in the clayey soil (Figure 2A), which can be attributed to the high initial concentration of ammoniacal $\mathrm{N}$ added into the soil, what is in agreement with a work carried out with SS (Misselbrook et al., 2002).

By adding urea, volatilization starts after enzymatic hydrolysis and ammoniacal $\mathrm{N}$ release. In the sandy soil, no difference was found between the fertilizers on the third day of evaluation, probably because of the soil structure, which may have favored nitrate leaching.

The use of DCD together with the SS in the clayey soil (Figure 2A) reduced the $\mathrm{NH}_{3}$ emission when compared to the SS without DCD on the third day, while in the sandy soil, DCD had no effect. The higher presence of $\mathrm{NH}_{4}^{+}$in the soil with the use of DCD did not increase $\mathrm{NH}_{3}$ emission because soils with a greater clay content have a lower tendency to lose $\mathrm{N}$ in the form of $\mathrm{NH}_{3}$ due to their higher buffering capacity and the higher capacity of retaining ammonium.

For the mode of application of the $\mathrm{N}$ sources to the soil, the injection showed lower emission of $\mathrm{NH}_{3}$ in relation to the surface application at the peak of volatilization in the clayey soil (Figure 2C). This reduction is due to the lower exposure of the manure to the air and to the higher $\mathrm{N}$-ammoniacal retention in the soil particles (Dell et al., 
2012). In the sandy soil, no difference in the volatilization of $\mathrm{NH}_{3}$ was found between modes of application at the peak of emission (Figure 2D). The effect of temperature on volatilization of $\mathrm{NH}_{3}$ may also have favored this loss. Tasca et al. (2011) found that the emissions occurring with the addition of urea in a Cambisol were $30 \%$ higher at
$35{ }^{\circ} \mathrm{C}$ than at $18{ }^{\circ} \mathrm{C}$. In this experiment, the peak of volatilization coincided with maximum temperature higher than $35^{\circ} \mathrm{C}$ (Figure 1), mainly when the fertilizers were applied on the surface.

Correcting soil pH (Figure 1E, Figure 2F) influenced the volatilization of $\mathrm{NH}_{3}$ on both soils on the third
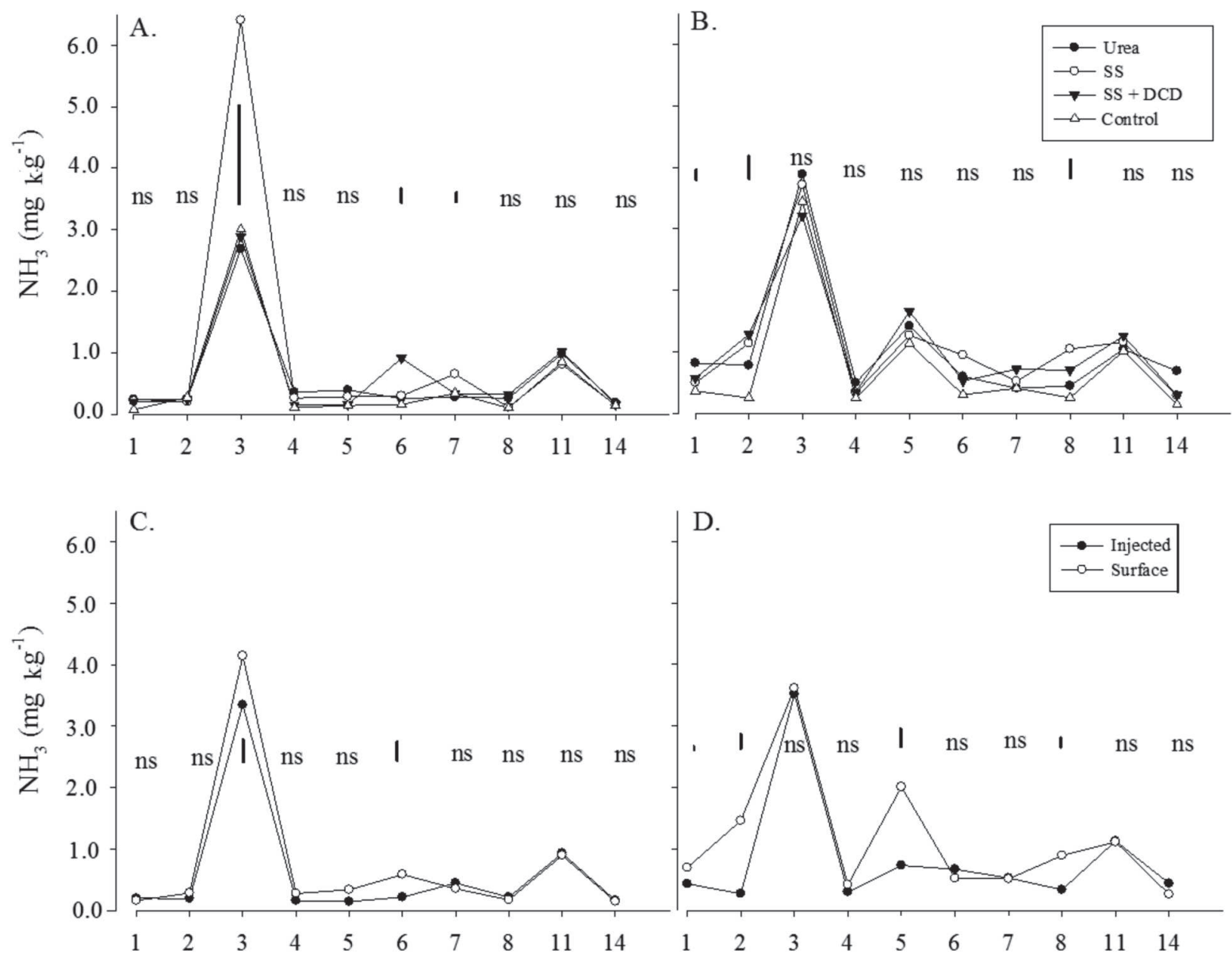

D.
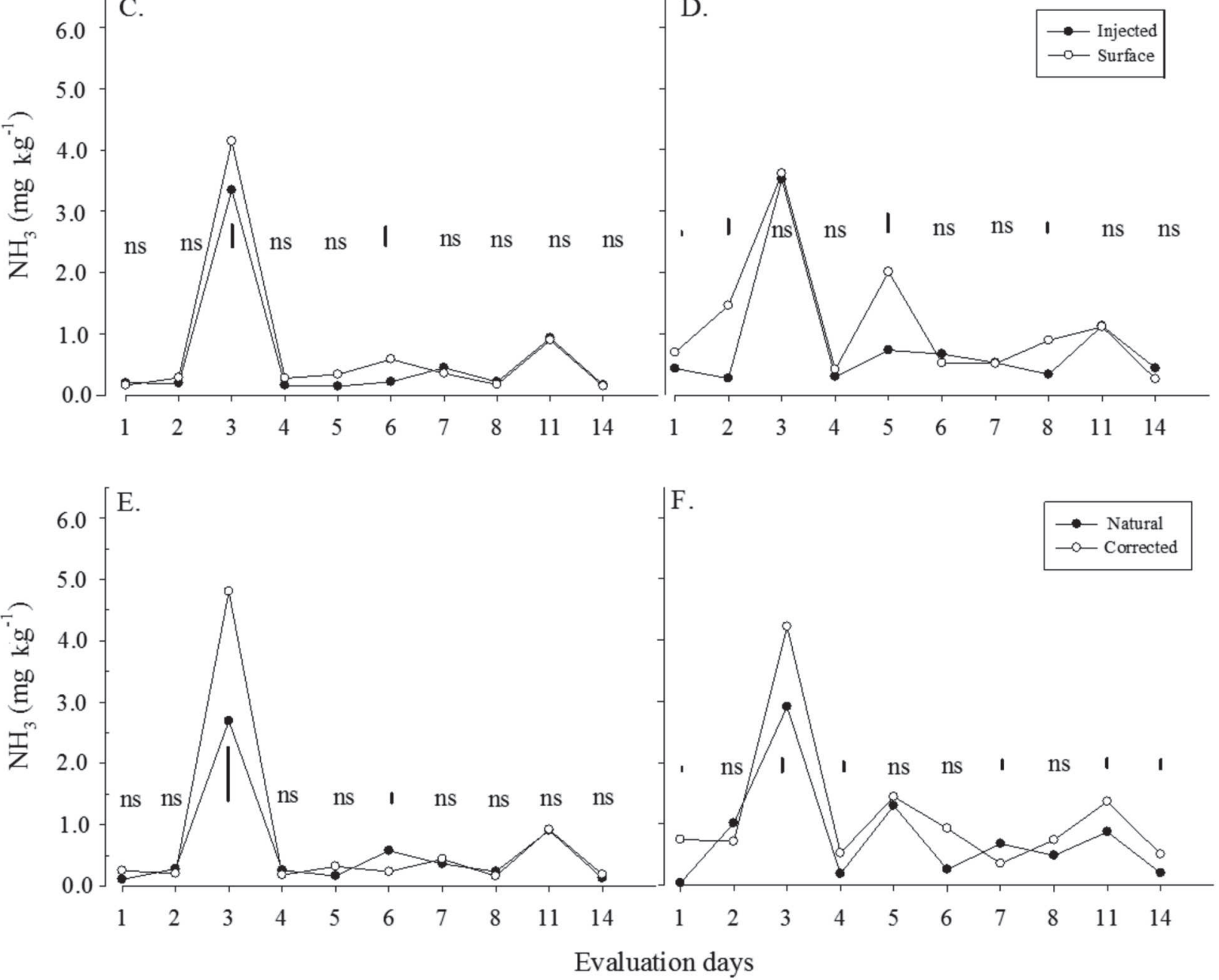

Figure 2: Main effect for daily ammonia volatilization from application of fertilizers (Urea, SS, SS+DCD, and Control), with two application modes (Injected and Surface), two pH conditions (Natural and Corrected) in a Rhodic Kandiudox (A, C, E) and Typic Hapludult (B, D, F). Vertical bars: represent the minimum significant difference by the Tukey's test ( $\mathrm{p}<0.05)$; ns: not significant. SS: swine slurry. DCD: Dicyandiamide. 
evaluation day, when limed soil had higher emission. The absence of acid sites $\left(\mathrm{H}^{+}\right)$prevents ammonia gas from returning to the mineral $\mathrm{N}\left(\mathrm{NH}_{4}^{+}\right)$form, which contributes to the intensification of emissions.

\section{Observed and theoretical accumulated ammonia volatilization}

By analyzing $\mathrm{NH}_{3}$ theoretical maximum loss (Table 1), it can be observed that with the addition of SS in the clayey soil with corrected $\mathrm{pH}$ on the surface application, the emission would reach $21.7 \mathrm{mg} \mathrm{kg}^{-1}$, indicating that on day $14,92 \%$ of maximum volatilization would be reached. However, the greatest difference between the observed value and the theoretical maximum occurred in the treatment where SS + DCD was applied in the clayey soil at natural $\mathrm{pH}$ and with surface application, which represented an additional loss of $29.8 \%$, indicating that on the $14^{\text {th }}$ day, $70 \%$ of theoretical maximum volatilization would be reached.

In the sandy soil, accumulated theoretical losses that had the largest difference between the observed accumulated value and the theoretical (Table 1), occurred due to the application of SS (17.8 $\left.\mathrm{mg} \mathrm{kg}^{-1}\right)$ and SS + DCD $\left(17.8 \mathrm{mg} \mathrm{kg}^{-1}\right)$ on the surface with adjusted $\mathrm{pH}$, followed by SS injection with adjusted $\mathrm{pH}\left(15.4 \mathrm{mg} \mathrm{kg}^{-1}\right)$, where both indicate that $80 \%, 81 \%$ and $78 \%$ of the maximum volatilization would be reached on the $14^{\text {th }}$ day, respectively.

\section{Effect of interaction of treatments on accumulated ammonia volatilization}

It is observed in the accumulated emissions of ammonia (Table 2) that in clayey soil at natural $\mathrm{pH}$ (4.8), the highest emission occurred in the SS + DCD on the surface $(8.48$ $\left.\mathrm{mg} \mathrm{kg}^{-1}\right)$, which was similar to that where SS $(6.32 \mathrm{mg} \mathrm{kg}$ $\left.{ }^{1}\right)$ and urea (6.69 $\left.\mathrm{mg} \mathrm{kg}^{-1}\right)$ were added. The fertilizers injected in the clayey soil at natural $\mathrm{pH}$ presented the lowest accumulated $\mathrm{NH}_{3}$ volatilization, which is equivalent to the addition of urea and SS on the surface. For the emissions that had occurred in the clayey soil under adjusted $\mathrm{pH}$ (6.0) the addition of SS to the surface showed the highest accumulated $\mathrm{NH}_{3}$ emission (19.9 $\mathrm{mg} \mathrm{kg}^{-1}$ ), differing from the other treatments.

The highest emissions due to the addition of SS to the surface in the clayey soil at natural and corrected $\mathrm{pH}$ may be attributed to the high ammoniacal $\mathrm{N}$ content of the SS $\left(4.2 \mathrm{~kg} \mathrm{~m}^{-3}\right)$, which promotes $\mathrm{NH}_{3}$ volatilization, and to the surface application, which facilitates gas exchange. In addition, the acidity correction results in a lower amount of $\mathrm{H}^{+}$ions and there would be less transformation of $\mathrm{NH}_{3}$ into $\mathrm{NH}_{4}{ }^{+}$.

The accumulated emission of $\mathrm{NH}_{3}$ with addition of urea on surface of the clayey soil (Table 2) may be related to the ammonification of urea, which increases the $\mathrm{pH}$ of the soil in micro sites, due to the consumption of protons $\left(\mathrm{H}^{+}\right)$and, consequently, increasing $\mathrm{NH}_{3}$ emissions (Chen et al., 2013). Webb et al. (2014),

Table 1: Observed and theoretical accumulated ammonia $\left(\mathrm{mg} \mathrm{kg}^{-1}\right)$, with addition of fertilizers (SS, SS + DCD, urea) applied in two conditions of $\mathrm{pH}$ (natural and corrected) and two modes of application (injected and surface), in a Rhodic Kandiudox and a Typic Hapludult soil

\begin{tabular}{|c|c|c|c|c|}
\hline Treatment & $\begin{array}{c}\text { Observed } \\
\text { accumulated } \\
\text { volatilization }^{1 \mathrm{a}}\end{array}$ & $\begin{array}{c}\text { Theoretical } \\
\text { accumulated } \\
\text { volatilization }\end{array}$ & $\begin{array}{c}\text { Observed } \\
\text { accumulated } \\
\text { volatilization }^{\text {1a }}\end{array}$ & $\begin{array}{c}\text { Theoretical } \\
\text { accumulated } \\
\text { volatilization }^{1 \mathrm{~b}}\end{array}$ \\
\hline & \multicolumn{4}{|c|}{ Rhodic Kandiudox } \\
\hline & \multicolumn{2}{|c|}{ Natural pH } & \multicolumn{2}{|c|}{ Corrected $\mathrm{pH}$} \\
\hline SS-Injected & 4.46 & $\mathrm{y}=6.891 *\left(1-\mathrm{e}^{-0.081 * x}\right)$ & 7.10 & $\mathrm{y}=8.7743^{*}\left(1-\mathrm{e}^{-0.2063^{*}}\right)$ \\
\hline $\mathrm{SS}+\mathrm{DCD}-$ Injected & 5.11 & $y=7.617 *\left(1-e^{-0.085 * x}\right)$ & 6.17 & $\mathrm{y}=6.9437 *\left(1-\mathrm{e}^{0.1729 *}\right)$ \\
\hline Urea - Injected & 3.70 & $\mathrm{y}=5.986 *\left(1-\mathrm{e}^{-0.071^{*} \mathrm{x}}\right)$ & 6.31 & $y=7.6653 *\left(1-e^{0.1339 * x}\right)$ \\
\hline SS - Surface & 6.32 & $\mathrm{y}=7.234 *\left(1-\mathrm{e}^{-0.168^{*} \mathrm{x}}\right)$ & 19.8 & $y=21.699 *\left(1-e^{-0.265^{*} x}\right)$ \\
\hline SS +DCD - Surface & 8.48 & $y=12.096^{*}\left(1-e^{0.105^{*} x}\right)$ & 5.85 & $\mathrm{y}=6.653^{*}\left(1-\mathrm{e}^{0.159 * x}\right)$ \\
\hline \multirow[t]{3}{*}{ Urea-Surface } & 6.69 & $\mathrm{y}=7.608^{*}\left(1-\mathrm{e}^{-0.183^{*} x}\right)$ & 7.07 & $y=7.984 *\left(1-e^{-0.172 * x}\right)$ \\
\hline & \multicolumn{4}{|c|}{ Typic Hapludult } \\
\hline & \multicolumn{2}{|c|}{ Natural pH } & \multicolumn{2}{|c|}{ Corrected $\mathrm{pH}$} \\
\hline SS - Injected & 7.58 & $\mathrm{y}=8.377 *\left(1-\mathrm{e}^{-0.190 * x}\right)$ & 12.11 & $\mathrm{y}=15.452 *\left(1-\mathrm{e}^{-0.131^{*} \mathrm{x}}\right)$ \\
\hline SS +DCD- Injected & 6.75 & $\mathrm{y}=8.668 *\left(1-\mathrm{e}^{-0.121^{*} x}\right)$ & 8.53 & $\mathrm{y}=11.342 *\left(1-\mathrm{e}^{-0.111^{*} \mathrm{x}}\right)$ \\
\hline Urea - Injected & 7.35 & $y=10.288 *\left(1-e^{-0.103 * x}\right)$ & 11.77 & $y=13.423^{*}\left(1-e^{-0.132^{*} x}\right)$ \\
\hline SS - Surface & 9.90 & $y=10.803 *\left(1-e^{-0.214^{*} x}\right)$ & 14.18 & $y=17.844^{*}\left(1-e^{-0.127^{*} x}\right)$ \\
\hline SS +DCD - Surface & 12.72 & $\mathrm{y}=14.614 *\left(1-\mathrm{e}^{-0.172^{*} \mathrm{x}}\right)$ & 14.47 & $y=17.807 *\left(1-e^{-0.178^{*} x}\right)$ \\
\hline Urea - Surface & 12.72 & $\mathrm{y}=14.614 *\left(1-\mathrm{e}^{-0.172 * x}\right)$ & 15.56 & $\mathrm{y}=17.117 *\left(1-\mathrm{e}^{-0.154^{*} \mathrm{x}}\right)$ \\
\hline
\end{tabular}

SS: swine slurry; DCD: Dicyandiamide; ${ }^{1 a}$ Cumulative loss values discounted from the emissions of the control; ${ }^{1 b}$ Equation of accumulated ammonia loss adjusted by Mitscherlich's model. 
injected animal manure into a clayey and sandy soil, and found a reduction in $\mathrm{NH}_{3}$ emission in relation to surface application.

Effects of DCD on ammonia volatilization can be variable. Zaman \& Blennerhassett (2010), mixed DCD with animal urine and observed an increase in $\mathrm{NH}_{3}$ emissions; on the other hand, Pujol (2012), added DCD to SS and concluded that there was no increase in $\mathrm{NH}_{3}$ emission in a sandy soil. Ni et al. (2014), applied DCD with urea on the surface of a sandy soil, and did not observed any increase in accumulated ammonia emissions.

By comparing the two $\mathrm{pH}$ conditions (Table 2) in the clayey soil, the $\mathrm{pH}$ correction resulted in the highest ammonia emissions in relation to the natural $\mathrm{pH}$ occurred, except for the application of SS + DCD on the surface $\left(5.85 \mathrm{mg} \mathrm{kg}^{-1}\right)$.

In the emissions verified in the sandy soil (Table 2) under natural $\mathrm{pH}$ (4.2), no effect of DCD was found. The highest emissions occurred in the treatments with $\mathrm{SS}+$ DCD (12.72 $\mathrm{mg} \mathrm{kg}^{-1}$ ) and SS (9.90 $\left.\mathrm{mg} \mathrm{kg}^{-1}\right)$, both applied on the surface. Aita et al. (2014) studied the injection of SS + DCD in sandy soil and verified that the emissions of $\mathrm{NH}_{3}$ were smaller, in relation to the superficial application. For the limed sandy soil ( $\mathrm{pH}$ 6.8) all treatments had higher $\mathrm{NH}_{3}$ emissions, compared to the natural $\mathrm{pH}$, except for the injected treatments, where the lowest emission was observed in the SS + DCD treatment $\left(8.53 \mathrm{mg} \mathrm{kg}^{-1}\right)$. Tasca et al. (2011), evaluating the volatilization of $\mathrm{NH}_{3}$ with the addition of urea in Cambisols with corrected (6.0) and natural $\mathrm{pH}$ (5.5), concluded that volatilization of $\mathrm{NH}_{3}$ increased in the limed soil.

The highest accumulated emissions observed with fertilizers applied on the surface are in accordance with Gonzatto et al. (2013), who by adding $60 \mathrm{~m}^{3} \mathrm{ha}^{-1} \mathrm{SS}$ on the surface of an sandy soil, observed an increase in the volatilization of $\mathrm{NH}_{3}$.

\section{Effect of the interaction between treatments on the percentage of $N$ lost by volatilization}

The percentage of $\mathrm{N}$ lost by $\mathrm{NH}_{3}$ volatilization (Table 3 ) in the clayey soil showed no difference between treatments with natural $\mathrm{pH}$. A difference was found between the two $\mathrm{pH}$ conditions in the treatment with SS + DCD applied to the surface, where the largest loss of $\mathrm{N}$ (22.4\%) occurred in the corrected $\mathrm{pH}$.

In the sandy soil (Table 3) in natural $\mathrm{pH}$, the highest percentage of lost N occurred in the SS + DCD applied on the surface $(6.8 \%)$, equivalent to the SS with no DCD. In this same soil with corrected $\mathrm{pH}$, the lowest $\mathrm{N}$ loss was observed in the injected SS + DCD, which is similar to the treatment with injected urea. Treatments under acid soil conditions showed lower N loss, except the SS + DCD surface treatment which was similar to the condition of corrected soil (Table 3).

Table 2: Volatilization of accumulated ammonia, with addition of fertilizers (Urea, SS, SS + DCD,) applied in two pH conditions (natural and corrected) and two modes of application (injected and surface), in a Rhodic Kandiudox and a Typic Hapludult soil

\begin{tabular}{|c|c|c|c|c|c|}
\hline Treatment & $\begin{array}{l}\text { Accumulated } \\
\text { ammonia } \\
\left(\mathrm{mg} \mathrm{kg}^{-1}\right)\end{array}$ & Treatment & $\begin{array}{c}\text { Accumulated } \\
\text { ammonia } \\
\left(\mathrm{mg} \mathrm{kg}^{-1}\right)\end{array}$ & LSD ${ }^{\text {(Fertilizer) }}$ & CV \% \\
\hline \multicolumn{2}{|c|}{ Rhodic Kandiudox with natural $\mathrm{pH}$} & \multicolumn{2}{|c|}{ Rhodic Kandiudox with adjusted $\mathrm{pH}$} & & \\
\hline SS - Injected & $4.46 \mathrm{Ab}$ & SS - Injected & $7.10 \mathrm{Ab}$ & 4.92 & 17.2 \\
\hline SS +DCD - Injected & $5.11 \mathrm{Ab}$ & $\mathrm{SS}+\mathrm{DCD}-$ Injected & $6.17 \mathrm{Ab}$ & 1.42 & 11.1 \\
\hline Urea - Injected & $3.70 \mathrm{Bb}$ & Urea - Injected & $6.31 \mathrm{Ab}$ & 1.24 & 10.9 \\
\hline SS - Surface & $6.32 \mathrm{Bab}$ & SS - Surface & $19.9 \mathrm{Aa}$ & 8.42 & 18.2 \\
\hline SS +DCD - Surface & $8.48 \mathrm{Aa}$ & SS +DCD - Surface & $5.85 \mathrm{Bb}$ & 1.74 & 10.8 \\
\hline Urea - Surface & $6.69 \mathrm{Aab}$ & Urea - Surface & $7.07 \mathrm{Ab}$ & 3.81 & 18.4 \\
\hline LSD (Mode of application) & 3.01 & LSD (Mode of application) & 7.31 & & \\
\hline $\mathrm{CV} \%$ & 18.9 & $\mathrm{CV} \%$ & 18.5 & & \\
\hline \multicolumn{2}{|c|}{ Typic Hapludult with natural $\mathrm{pH}$} & \multicolumn{2}{|c|}{ Typic Hapludult com adjusted pH } & & \\
\hline SS - Injected & $7.58 \mathrm{Bb}$ & SS - Injected & $12.11 \mathrm{Aab}$ & 4.51 & 19.2 \\
\hline $\mathrm{SS}+\mathrm{DCD}-$ Injected & $6.75 \mathrm{Ab}$ & SS +DCD - Injected & $8.53 \mathrm{Ab}$ & 2.57 & 14.8 \\
\hline Urea - Injected & $7.35 \mathrm{Bb}$ & Urea - Injected & 11.77 Aab & 3.51 & 16.2 \\
\hline SS - Surface & 9.90 Bab & SS - Surface & $14.18 \mathrm{Aa}$ & 2.13 & 7.8 \\
\hline SS +DCD- Surface & $12.72 \mathrm{Aa}$ & SS +Inhibitor - Surface & $14.47 \mathrm{Aa}$ & 4.41 & 14.3 \\
\hline Urea - Surface & $7.83 \mathrm{Bb}$ & Urea - Surface & $15.56 \mathrm{Aa}$ & 2.65 & 9.6 \\
\hline LSD (Mode of application) & 4.1 & LSD (Mode of application) & 4.1 & & \\
\hline $\mathrm{CV} \%$ & 17.1 & $\mathrm{CV} \%$ & 11.8 & & \\
\hline
\end{tabular}

LSD: least significant difference; CV: coefficient of variation; Upper case letters compare fertilizers applied in the same soil in different $\mathrm{pH}$; Lower case letters compare fertilizers with mode of application in the same soil at equal $\mathrm{pH}$. Tukey ( $\mathrm{p}<0.05$ ). 
Table 3: Percentage of nitrogen loss in relation to the applied nitrogen from fertilizers (Urea, SS, SS + DCD) applied in two pH conditions (natural and corrected) and two modes of application (injected and surface), in a Rhodic Kandiudox and a Typic Hapludult soil

\begin{tabular}{|c|c|c|c|c|}
\hline Treatment & $\begin{array}{l}\text { Accumulated } \\
\text { ammonia (\%) }\end{array}$ & Treatment & $\begin{array}{l}\text { Accumulated } \\
\text { ammonia (\%) }\end{array}$ & LSD $^{\text {(Fertilizer) }}$ \\
\hline \multicolumn{2}{|c|}{ Rhodic Kandiudox with natural $\mathrm{pH}$} & \multicolumn{2}{|c|}{ Rhodic Kandiudox with adjusted $\mathrm{pH}$} & \\
\hline SS - Injected & $1.5 \mathrm{Aa}$ & SS - Injected & $4.23 \mathrm{Ab}$ & 7.58 \\
\hline SS +DCD - Injected & $2.4 \mathrm{Aa}$ & $\mathrm{SS}+\mathrm{DCD}-$ Injected & $1.78 \mathrm{Ab}$ & 2.03 \\
\hline Urea - Injected & $0.4 \mathrm{Aa}$ & Urea - Injected & $2.00 \mathrm{Ab}$ & 1.76 \\
\hline SS - Surface & $1.5 \mathrm{Ba}$ & SS - Surface & $22.4 \mathrm{Aa}$ & 12.42 \\
\hline SS +DCD - Surface & 4.6 Aa & $\mathrm{SS}+\mathrm{DCD}-$ Surface & $2.66 \mathrm{Ab}$ & 2.57 \\
\hline Urea - Surface & $2.0 \mathrm{Aa}$ & Urea - Surface & 4.1 Aa & 4.58 \\
\hline $\mathrm{LSD}^{\text {(Mode of application) }}$ & 4.31 & LSD (Mode of application) & 10.07 & \\
\hline \multicolumn{2}{|c|}{$\begin{array}{c}\text { Typic Hapludult with natural pH } \\
\end{array}$} & \multicolumn{2}{|c|}{ Typic Hapludult with adjusted $\mathrm{pH}$} & \\
\hline SS - Injected & $2.3 \mathrm{Bab}$ & SS - Injected & $8.5 \mathrm{Aa}$ & 4.23 \\
\hline SS +DCD - Injected & $1.2 \mathrm{Ab}$ & DLS+DCD - Injected & $2.5 \mathrm{Ab}$ & 3.72 \\
\hline Urea - Injected & $2.0 \mathrm{Bab}$ & Urea - Injected & 7.1 Aab & 5.01 \\
\hline SS - Surface & 3.7 Bab & SS - Surface & $8.0 \mathrm{Aa}$ & 3.06 \\
\hline SS +DCD- Surface & $6.8 \mathrm{Aa}$ & SS +Inhibitor - Surface & 8.4 Aa & 4.17 \\
\hline Urea - Surface & 2.1 Bab & Urea-Surface & $10.1 \mathrm{Aa}$ & 3.78 \\
\hline LSD (Mode of application) & 4.95 & LSD (Mode of application) & 4.82 & \\
\hline
\end{tabular}

LSD: least significant difference; Upper case letters compare fertilizers applied in the same soil in different $\mathrm{pH}$; Lower case letters compare fertilizers with mode of application in the same soil at equal $\mathrm{pH}$. Tukey $(\mathrm{p}<0.05)$.

\section{CONCLUSIONS}

Injection of fertilizers reduced the cumulative emission of ammonia in relation to the surface application in both soils.

The use of the nitrification inhibitor did not influence volatilization of ammonia in both soils.

The highest percentage of nitrogen lost by ammonia volatilization occurred in the surface application under conditions of corrected $\mathrm{pH}$ in the clayey soil.

\section{REFERENCES}

Aita C, Gonzatto R, Miola ECC, Santos DB dos, Rochette P, Angers DA, Chantigny MH, Pujol SB, Giacomini DA \& Giacomini SJ (2014) Injection of dicyandiamide-treated pig slurry reduced ammonia volatilization without enhancing soil nitrous oxide emissions from no-till corn in southern Brazil. Journal Environmental Quality, 43:789-800.

Cameron KC, Di HJ \& Moir JL (2013) Nitrogen losses from the soil/plant system: a review. Annals of Applied Biology, 162:145173

Clay DE, Carlson CG, Clay SA \& Murrell TS (2012) Mathematics and calculations for agronomists and soil scientists. Norcross, GA. 238p.

CQFS - Comissão de Química e Fertilidade do Solo (2016) Manual de calagem e adubação para os estados do Rio Grande do Sul e Santa Catarina. $11^{\text {a }}$ ed. Frederico Westphalen, SBCS. 376p.

Chen CR, Phillips IR, Condron LM, Goloran J, Xu ZH \& Chan KY (2013) Impacts of greenwaste biochar on ammonia volatilisation from bauxite processing residue sand. Plant Soil, 367:301-312.

Dell CJ, Kleinman PJ, Schmidt JP \& Beegle DB (2012) Lowdisturbance manure incorporation effects on ammonia and nitrate loss. Journal of Environmental Quality, 41:928-937.
Embrapa - Empresa Brasileira de Pesquisa Agropecuária (1997) Centro Nacional de Pesquisa de Solos. Manual de métodos de análise de solo. $2^{\mathrm{a}}$ ed. Rio de Janeiro, Embrapa. 212p.

Gonzatto R, Miola ECC, Doneda A, Pujol SB, Aita C \& Giacomini SJ (2013) Volatilização de amônia e emissão de óxido nitroso após aplicação de dejetos líquidos de suínos em solo cultivado com milho. Ciência Rural, 43:1590-1596.

Gonzatto R, Stüker F, Aita C, Giacomini SJ, Lüdtke RC, Dessbesell A, Giacomini SJ \& Pujol SB (2016) Dicyandiamide as nitrification inhibitor of pig slurry ammonium nitrogen in soil. Ciência $\mathrm{Ru}-$ ral, 46:802-808.

Kim D, Saggar S \& Roudier P (2012) The effect of nitrification inhibitors on soil ammonia emissions in nitrogen managed soils: a meta-analysis. Nutrient Cycling in Agroecosystems, 93:51-64.

Misselbrook TH, Smith KA, Johnson RA \& Pain BF (2002) Slurry application techniques to reduce ammonia emissions: results of some UK field-scale experiments. Biosystems Engineering, $81: 313-321$.

Ni K, Pacholski A \& Kage H (2014) Ammonia volatilization after application of urea to winter wheat over 3 years affected by novel urease and nitrification inhibitors. Agriculture, Ecosystems \& Environment 197: 184-194.

Pote DH \& Meisinger JJ (2014) Effect of poultry litter application method on ammonia volatilization from a conservation tillage system. Soil and Water Conservation, 69:17-25.

Pujol SB (2012) Emissão de amônia e dinâmica do nitrogênio no solo com parcelamento da dose e adição de inibidor de nitrificação em dejetos de suínos. Tese de Doutorado. Universidade Federal de Santa Maria, Santa Maria. 100p.

SAS Institute Inc. (2007) SAS 9.1.3 (TS1M3) para Windows Microsoft. Cary, Statistical Analysis System Institute. CD-ROM.

Singh N S \&Verma A (2008) The potential of nitrification inhibitors to manage the pollution effect of nitrogen fertilizers in agricultural and other soils: a review. Environmental Practice, 4:266-279.

Rev. Ceres, Viçosa, v. 64, n.3, p. 307-314, mai/jun, 2017 
Tasca FA, Ernani PR, Rogeri DA, Gatiboni LC \& Cassol PC (2011) Volatilização de amônia do solo após a aplicação de ureia convencional ou com inibidor de urease. Revista Brasileira de Ciência do Solo, 35:493-502.

Tedesco MJ, Gianello C, Bissani CA, Bohnen H \& Volkweiss SJ (1995) Análise de solo, planta e outros materiais. $2^{a}$ ed. Porto Alegre, Universidade Federal do Rio Grande do Sul. 174p. (Boletim Técnico, 5).

VanderZaag AC, Jayasundara S \& Wagner-Riddle C (2011) Strategies to mitigate nitrous oxide emissions from land applied manure. Animal Feed Science and Technology, 166: 464-479.

Webb J, Thorman RE, Fernanda-Aller M \& Jackson DR (2014) Emission factors for ammonia and nitrous oxide emissions following immediate manure incorporation on two contrasting soil types. Atmospheric Environment, 82:280-287.
Zaman M \& Blennerhassett JD (2010) Effects of the different rates of urease and nitrification inhibitors on gaseous emissions of ammonia and nitrous oxide, nitrate leaching and pasture production from urine patches in an intensive grazed pasture system. Agriculture, Ecosystems and Environment, 136:236246.

Zhang M, Fan CH, Li QL, Li B, Zhu YY \& Xiong ZQ (2015) A 2 year field assessment of the effects of chemical and biological nitrification inhibitors on nitrous oxide emissions and nitrogen use efficiency in an intensively managed vegetable cropping system. Agriculture, Ecosystems and Environment, 201:43-50. 